\title{
Uji Iritasi dan Uji Sifat Fisik Sediaan Gel Minyak Atsiri Daun Cengkeh (Syzygium aromaticum (L.) Merr. \& L.M.Perry) dengan Variasi Konsentrasi HPMC
}

\section{Skin-irritating Test and Physical Properties of Gel Containing Essential Oil of Clove (Syzygium aromaticum (L.) Merr. \& L.M.Perry) Leaves with Varied Concentrations of HPMC}

\author{
Fitri Kurniasari*, Jena Hayu Widyasti \\ Fakultas Farmasi, Universitas Setia Budi Surakarta \\ JI. Letjen Sutoyo, Mojosongo, Kec. Jebres, Kota Surakarta, Jawa Tengah 57127, Indonesia \\ *Corresponding author email: fitrinature@gmail.com
}

Received 25-01-2020 Accepted 09-04-2020 Available online 01-07-2020

\begin{abstract}
ABSTRAK
Inflamasi merupakan respon protektif normal terhadap luka jaringan yang disebabkan oleh trauma fisik, zat kimia yang merusak, atau zat-zat mikrobiologi. Salah satu bahan alam yang memiliki khasiat antiinflamasi adalah minyak atsiri daun cengkeh (Syzygium aromaticum (L.) Merr. \& L.M.Perry). Penelitian ini bertujuan untuk mengetahui kualitas minyak atsiri daun cengkeh, formulasi gel minyak atsiri, serta uji sifat fisik dan uji iritasinya. Minyak atsiri diperoleh dengan destilasi uap dan air. Minyak atsiri yang didapat digunakan dalam sediaan gel dengan konsentrasi hidroksipropil metilselulose (HPMC) 3\% (FI), HPMC 3\% dan minyak atsiri 6\% (FII), HPMC 6\% (FIII), HPMC 6\% dan minyak atsiri 6\% (FIV), HPMC 10\% (FV), serta HPMC 10\% dan minyak atsiri 6\% (FVI). Pengamatan terhadap gel meliputi uji organoleptik, homogenitas, $\mathrm{pH}$, uji daya lekat, dan uji daya sebar. Gel yang telah diuji sifat fisiknya, dievaluasi iritasinya terhadap kulit dengan metode Draize test. Data hasil pengujian dianalisis statistik dengan ANAVA satu arah dengan taraf kepercayaan $95 \%$. Dari penelitian yang telah dilakukan diperoleh hasil minyak atsiri daun cengkeh yaitu berwarna kuning kecoklatan dan berbau khas daun cengkeh dengan nilai rendemen sebesar 1,6\%, indeks bias sebesar 1,525, dan bobot jenis sebesar 1,02. Gel daun cengkeh memenuhi standar kualitas gel yaitu homogenitas, daya sebar, $\mathrm{pH}$, dan daya lekat. Analisis statistik terhadap masing-masing percobaan tidak menunjukkan perbedaan yang signifikan. Hasil percobaan terhadap uji iritasi menunjukkan bahwa sediaan gel tidak menimbulkan iritasi pada kulit marmut.
\end{abstract}

Kata kunci: gel, HPMC, minyak atsiri daun cengkeh, uji iritasi. 


\begin{abstract}
Inflammation is a normal protective response to tissue injury caused by physical trauma, damaging chemicals, or microbiological substances. Clove (Syzygium aromaticum (L.) Merr. \& L.M.Perry) leaves essential oil has shown anti-inflammatory properties. This study was aimed to determine the quality of clove essential oil, formulate it into gel preparation, and evaluate the physical properties as well as the skin-irritating potential of the gel. The essential oil was obtained from the water and steam distillation process. Essential oils were used in the gel preparations with 3\% hydroxypropyl methylcellulose (HPMC) (FI), 3\% HPMC and 6\% essential oil (FII), 6\% HPMC (FIII), 6\% HPMC and 6\% essential oil (FIV), 10\% HPMC (FV), as well as 10\% HPMC and $6 \%$ essential oil (FVI). The gels were evaluated for their organoleptic properties, i.e. color, odor, homogeneity, $\mathrm{pH}$, adhesion, and dispersion. Gels were also tested for its irritative properties on the skin of guinea pigs by the Draize test method. Test data was statistical analysis by one-way ANOVA with a confidence level of 95\%. The research showed that the clove essential oil was brownish yellow with a distinctive smell of clove leaves, with a yield of $1.6 \%$ as well as the refractive index and specific gravity of 1.525 and 1.02, respectively. The color, smell, homogeneity, dispersion, $\mathrm{pH}$, and adhesion of the gels were within the specified limit, with no statistical differences among the formula. The gels did not cause irritation to the skin of guinea pigs.
\end{abstract}

Key words: clove leaves (Eugenia aromatic L.), gel, HPMC, irritation.

\section{Pendahuluan}

Inflamasi merupakan respon

protektif normal terhadap luka jaringan yang disebabkan oleh trauma fisik, zat kimia yang merusak, atau zat-zat mikrobiologi. Salah satu bahan alam yang memiliki khasiat antiinflamasi adalah minyak atsiri daun cengkeh (Eugenia aromatic L.). Senyawa utama dalam daun cengkeh adalah eugenol yang merupakan komponen utama terhadap peran imunomodulator dan antiinflamasi (Daniel et al., 2009).

Daun cengkeh memiliki aktivitas farmakologi sebagai analgesik, antiinflamasi, antiviral, antiseptik, antispasmodik, antiemetik, stimulant, dan anastesi lokal (Pramod et al., 2010). Penelitian yang dilakukan oleh Nurdjannah (2004) menyebutkan bahwa eugenol merupakan komponen terbesar yang terdapat pada minyak atsiri cengkeh. Studi terdahulu mengungkapkan bahwa eugenol dan komponen fenolik lain memiliki aktivitas sebagai antioksidan dan antiinflamasi yang bekerja menghambat sintesis prostaglandin dan neutrophil chemotaxis (Ma \& Kinneer, 2002).

Penggunaan minyak atsiri daun cengkeh sebagai antiinflamasi dapat dipermudah dengan memformulasikannya dalam sediaan gel. Sediaan gel dipilih karena merupakan sediaan yang stabilitasnya baik, berupa sediaan halus, mudah digunakan, mampu menjaga kelembaban kulit, tidak mengiritasi kulit, mempunyai tampilan yang lebih menarik, dan lebih lama berada di jaringan luka dibandingkan 
dengan bentuk sediaan lain. Kandungan air yang tinggi dalam basis gel dapat menyebabkan terjadinya hidrasi pada stratum corneum sehingga akan memudahkan penetrasi obat melalui kulit (Kibbe, 2004).

Salah satu basis gel derivat selulosa adalah hidroksipropil metilselulose (HPMC) (Gibson, 2001). Pemilihan basis HPMC dikarenakan penampakan gel jernih dan kompatibel dengan bahan-bahan lain, kecuali bahanbahan yang oksidatif (Gibson, 2001) serta dapat mengembang terbatas dalam air sehingga merupakan bahan pembentuk hidrogel yang baik.

Gel kemudian dibuat dengan berbagai variasi konsentrasi basis HPMC yaitu 3,6 , dan $10 \%$, serta basis gel tanpa minyak atsiri. Evaluasi terhadap sifat fisik dan sifat iritatif pada sediaan topikal perlu dilakukan. Hal ini untuk menjamin bahwa sediaan memiliki efek farmakologis yang baik dan tidak mengiritasi kulit ketika digunakan. Sifat fisik sediaan mempengaruhi tercapainya efek farmakologis sesuai yang diharapkan. Parameter pengujian sifat fisik gel antara lain uji daya sebar, daya lekat, dan pH. Selain itu juga dievaluasi terhadap daya iritasi gel.

Penelitian ini penting dilakukan untuk mengetahui identifikasi kualitas minyak atsiri daun cengkeh serta formulasi terbaik gel antiinflamasi dengan basis HPMC. Uji iritasi bertujuan untuk mengetahui apakah sediaan gel menimbulkan reaksi iritatif terhadap kulit.

\section{Metode Penelitian}

Alat dan Bahan

Bahan yang digunakan dalam penelitian ini adalah daun cengkeh yang diperoleh dari Desa Sukorejo, Tugurejo, Musuk, Boyolali. HPMC, PEG, metil paraben, dan propil paraben. Hewan uji marmut jantan albino dengan rata-rata berat badan $500-600$ g. Peralatan yang digunakan adalah pengaduk, seperangkat alat gelas, cawan porselen, mortir, stamper, waterbath, timbangan analitik, alat uji daya sebar, alat uji daya lekat, piknometer, pemanas air, batang pengaduk, gelas ukur, piknometer, dan seperangkat alat destilasi.

\section{Jalannya Penelitian}

1. Destilasi daun cengkeh

Daun cengkeh

(Eugenia

aromatic L.) seberat $15 \mathrm{~kg}$ yang sudah bersih dari kotoran dimasukkan ke dalam ketel suling dan ditutup dengan rapat. Steam dari boiler dialirkan ke ketel suling dengan tekanan selama \pm 6 jam. Cairan yang keluar dari kondenser didiamkan selama 2 jam untuk memisahkan air dan minyak. Pada tahap pemurnian, minyak daun cengkeh ditambahkan dengan $\mathrm{Na}_{2} \mathrm{SO}_{4}$ pada suhu $50{ }^{\circ} \mathrm{C}$ sambil diaduk selama 1 jam, kemudian didiamkan selama 15 menit (Marwati et al., 2005).

2. Standarisasi minyak atsiri daun cengkeh

Standarisasi minyak atsiri daun cengkeh meliputi uji organoleptis, penetapan rendemen (Nuryoto et al., 2011), penetapan bobot jenis dan 
penetapan indeks bias (Prianto et al., 2013; Marwati et al., 2005).
Formula gel minyak atsiri daun cengkeh dapat dilihat pada Tabel 1.

3. Formula gel minyak atsiri daun cengkeh

Tabel 1. Formulasi gel minyak atsiri daun cengkeh

\begin{tabular}{lcccccc}
\hline \multicolumn{1}{c}{ Komposisi } & FI & FII & FIII & FIV & FV & FVI \\
\hline Minyak atsiri (mL) & - & 9 & - & 9 & - & 9 \\
HPMC (g) & 5 & 5 & 10 & 10 & 15 & 15 \\
Propilenglikol (g) & 15 & 15 & 15 & 15 & 15 & 15 \\
Propilparaben (g) & 0,15 & 0,15 & 0,15 & 0,15 & 0,15 & 0,15 \\
Metilparaben (g) & 0,18 & 0,18 & 0,18 & 0,18 & 0,18 & 0,18 \\
Akuades ad mL & 150 & 150 & 150 & 150 & 150 & 150 \\
\hline
\end{tabular}

4. Evaluasi sediaan gel minyak atsiri daun cengkeh

Evaluasi sediaan gel minyak atsiri daun cengkeh menggunakan jenis pengujian stabilitas fisik yang merupakan persyaratan sediaan gel, yaitu uji organoleptik, homogenitas, $\mathrm{pH}$, dan daya sebar.

Pemeriksaan organoleptis

Pengamatan terhadap bentuk, warna, dan bau dilakukan secara visual (Depkes RI, 1995).

Pemeriksaan homogenitas

Pemeriksaan terhadap homogenitas dilakukan dengan cara: sediaan ditimbang $100 \mathrm{mg}$ kemudian dioleskan pada kaca objek atau bahan transparan lain yang cocok dan susunannya diamati.

\section{Pemeriksaan $\mathrm{pH}$}

Pengukuran $\mathrm{pH}$ menggunakan $\mathrm{pH}$ meter. Pengukuran $\mathrm{pH}$ gel dilakukan dengan cara: 1 gram basis disuspensikan dengan air suling panas hingga $10 \mathrm{~mL}$. Elektroda dicelupkan dalam wadah tersebut, jarum dibiarkan bergerak sampai posisi konstan. Angka yang ditunjukkan oleh $\mathrm{pH}$ meter merupakan nilai $\mathrm{pH}$ sediaan tersebut (Sanjay et al., 2007; Agnihotri et al., 2016).

Uji daya menyebar

Setengah gram sediaan dituang pada permukaan kaca transparan yang beralaskan kertas grafik. Sediaan dibiarkan menyebar selama 15 detik, kemudian ditutup dengan plastik transparan dan diberi beban tertentu (1, 3, 5, dan 7 gram) selama 60 detik. Pertambahan diameter diukur setelah diberikan beban (Voigt, 1994; Agnihotri et al., 2016).

Uji daya melekat

Uji daya melekat dilakukan dengan mengoleskan sediaan pada area $2 \times 2 \mathrm{~cm}$ yang diletakkan obyek gelas lain di atasnya. Beban seberat 1 kg diberikan selama 5 menit. Waktu hingga lekatan terlepas dihitung dengan menurunkan beban 80 gram.

5. Evaluasi daya iritasi sediaan gel Pengujian dilakukan terhadap hewan uji marmut dengan menggunakan metode Draize (1959). 
Uji dilakukan dengan menggunakan 6 ekor marmut berumur rata-rata 2 bulan. Rambut marmut dicukur pada bagian punggungnya sampai bersih. Punggung marmut dibagi menjadi 6 bagian dengan luas yang sama kemudian diberikan perlakuan sediaan gel FI, FII, FIII, FIV, FV, dan FVI. Masing-masing sampel iritan sebanyak 0,5 gram dioleskan pada bagian punggung marmut yang telah dicukur, lalu ditutup dengan kasa steril kemudian direkatkan dengan plester. Setelah 24 jam, plester dibuka dan dibiarkan selama 1 jam, lalu diamati. Setelah diamati, bagian tersebut ditutup kembali dengan plester yang sama dan dilakukan pengamatan kembali setelah 72 jam. (Irsan et al., 2013).

\section{Hasil dan Pembahasan \\ Parameter Minyak Atsiri Daun Cengkeh Berdasarkan Standar SNI}

Tujuan pengujian minyak atsiri adalah untuk menjamin bahwa minyak atsiri yang diperoleh memenuhi standar kualitas (Prianto et al., 2013; Nuryoto et al., 2011; Marwati et al., 2005). Selain itu juga untuk mengetahui kemurnian dari minyak atsiri daun cengkeh yang dihasilkan. Hasil standardisasi minyak atsiri dapat dilihat di Tabel 2.

Evaluasi Sediaan Gel

Evaluasi sediaan gel meliputi pengamatan stabilitas fisik yang terdiri dari uji organoleptis, homogenitas, $\mathrm{pH}$, konsistensi, dan daya sebar. Hasil pemeriksaan sifat fisik gel dapat dilihat pada Tabel 3.

Tabel 2. Hasil standardisasi minyak atsiri

\begin{tabular}{llc}
\hline \multicolumn{1}{c}{ Karakteristik } & \multicolumn{1}{c}{ Hasil Penelitian } & \multicolumn{1}{c}{ Standar SNI } \\
\hline Uji Organoleptis & Kuning, khas minyak cengkeh & Kuning - coklat tua khas \\
Rendemen (\%) & 1,6 & \\
Indeks Bias & 1,525 & $1,5200-1,5400$ \\
Bobot Jenis & 1,02 & $1,0250-1,0609$ \\
\hline
\end{tabular}

Tabel 3. Hasil pemeriksaan sifat fisik gel

\begin{tabular}{|c|c|c|c|c|c|c|c|}
\hline Parameter & $\mathbf{F I}$ & FII & FIII & FIV & FV & FVI & SNI \\
\hline \multicolumn{8}{|l|}{ Organoleptis } \\
\hline Warna & Jernih & Putih & Putih & Putih & Putih & Putih & Jernih-kuning \\
\hline Aroma & $\begin{array}{l}\text { Aroma } \\
\text { cengkeh }\end{array}$ & $\begin{array}{l}\text { Aroma } \\
\text { cengkeh }\end{array}$ & $\begin{array}{l}\text { Aroma } \\
\text { cengkeh }\end{array}$ & $\begin{array}{l}\text { Aroma } \\
\text { cengkeh }\end{array}$ & $\begin{array}{l}\text { Aroma } \\
\text { cengkeh }\end{array}$ & $\begin{array}{l}\text { Aroma } \\
\text { cengkeh }\end{array}$ & $\begin{array}{l}\text { Aroma } \\
\text { cengkeh }\end{array}$ \\
\hline Homogenitas & Homogen & Homogen & Homogen & Homogen & Homogen & Homogen & Homogen \\
\hline Daya sebar $(\mathrm{cm})$ & 7,6 & 5,7 & 3,4 & 4,4 & 3,6 & 5 & 5-7 \\
\hline $\begin{array}{l}\text { Konsistensi } \\
\mathrm{pH}\end{array}$ & $\begin{array}{c}\text { Kental } \\
6,26\end{array}$ & $\begin{array}{c}\text { Kental } \\
6,80\end{array}$ & $\begin{array}{c}\text { Kental } \\
6,63\end{array}$ & $\begin{array}{c}\text { Kental } \\
6,50\end{array}$ & $\begin{array}{c}\text { Kental } \\
6,52\end{array}$ & $\begin{array}{c}\text { Kental } \\
6,3\end{array}$ & $\begin{array}{l}\text { Kental } \\
4,5-7\end{array}$ \\
\hline $\begin{array}{l}\text { Daya lekat } \\
\text { (detik) }\end{array}$ & 0,29 & 0,92 & 2,37 & 2,43 & 4,61 & 5,10 & $>1$ \\
\hline
\end{tabular}


1. Pengujian organoleptis

Hasil uji organoleptis menunjukkan bahwa semua sediaan gel berbentuk setengah padat dengan aroma khas minyak atsiri daun cengkeh.

\section{Homogenitas}

Semua formula sediaan gel daun cengkeh memenuhi persyaratan homogenitas. Pada tabel hasil uji homogenitas ini menunjukkan tidak adanya pengaruh variasi konsentrasi HPMC terhadap homogenitas gel

3. Uji daya sebar

Hasil daya sebar sediaan gel yang baik $5-7 \mathrm{~cm}$, kecuali formula III dan formula IV. Semakin besar daya sebar yang diberikan, maka kemampuan zat aktif untuk menyebar dan kontak dengan kulit semakin luas (Niazi, 2004). Pengujian daya sebar bertujuan untuk mengetahui seberapa baik sediaan gel menyebar di permukaan kulit, karena dapat mempengaruhi absorbsi obat dan kecepatan pelepasan zat aktif di tempat pemakaiannya. Suatu sediaan yang baik dan lebih disukai bila dapat menyebar dengan mudah di kulit dan nyaman digunakan (Wyatt et al., 2008). Grafik daya sebar dapat dilihat pada Gambar 1.

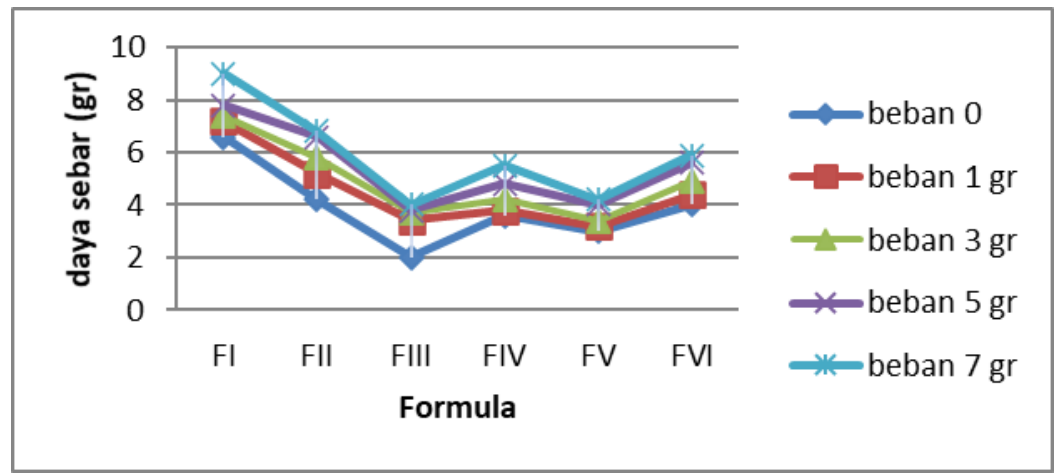

Gambar 1. Grafik hubungan formula gel minyak atsiri daun cengkeh dengan daya sebar.

4. $\mathrm{Uji} \mathrm{pH}$

Tujuan dari uji $\mathrm{pH}$ adalah untuk melihat tingkat keasaman sediaan serta menjamin sediaan tidak menyebabkan iritasi pada kulit (Draelos \& Laurend, 2006). Kulit yang normal mempunyai pH antara 4,5-7, sehingga sediaan topikal harus memiliki $\mathrm{pH}$ yang sama dengan $\mathrm{pH}$ normal kulit tersebut. Kesesuaian $\mathrm{pH}$ kulit dengan gel mempengaruhi penerimaan kulit terhadap sediaan. Berdasarkan hasil pengujian diketahui pH sediaan adalah 6,26-6,80 yang memenuhi persyaratan $\mathrm{pH}$ untuk sediaan gel. Formula I $(6,2)$, formula II $(6,8)$, formula III $(6,6)$, formula IV $(6,5)$, formula $V(6,52)$, dan formula VI 
$(6,3)$. Hasil analisis statistik

dikarenakan HPMC mampu menunjukkan tidak terlihat membentuk koloid dengan perbedaan bermakna antara semua penambahan air panas (Rowe et al., formula, yang berarti tidak ada 2009). Koloid terbentuk karena zat pengaruh variasi konsentrasi HPMC terhadap $\mathrm{pH}$ gel. Grafik hubungan formula gel minyak atsiri daun cengkeh dengan $\mathrm{pH}$ dapat dilihat pada grafik di Gambar 2.

4. Uji daya lekat

Tujuan dari uji daya lekat ini adalah untuk mengetahui seberapa besar kemampuan gel melekat pada kulit dalam waktu tertentu sehingga dapat berfungsi secara maksimal pada penghantaran obatnya. Tidak ada persyaratan khusus mengenai daya lekat sediaan semipadat, namun sebaiknya daya lekat sediaan semipadat adalah lebih dari 1 detik (Zats \& Gregory, 1996).

Hasil uji daya lekat gel pada gambar menunjukkan semakin meningkatnya kadar HPMC yang digunakan tiap formula maka waktu terdispersinya mengabsorbsi medium pendispersinya sehingga menjadi kental dan bersifat lengket, oleh sebab itu semakin tinggi kadar HPMC maka koloid yang terbentuk akan semakin banyak dan mampu meningkatkan daya lekatnya. Dari hasil statistik variasi konsentrasi HPMC terhadap daya lekat terjadi pada FIII dan IV, begitu juga FV terhadap $\mathrm{FVI}$, hal ini dikarenakan konsentrasi HPMC yang berbeda pada FIII dan FV tanpa penambahan minyak atsiri (basis), begitu juga pada FIV dan FVI yang mengandung konsentrasi minyak atsiri $6 \%$ dengan variasi konsentrasi HPMC yang berbeda. Grafik hubungan daya lekat dengan formula gel minyak atsiri daun cengkeh dapat dilihat pada Gambar 3.

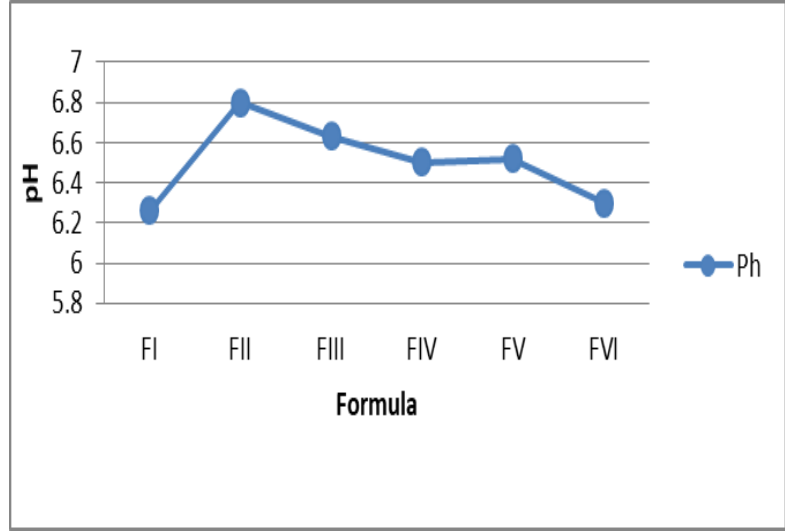

Gambar 2. Grafik hubungan formula gel minyak atsiri daun cengkeh dengan $\mathrm{pH}$. 


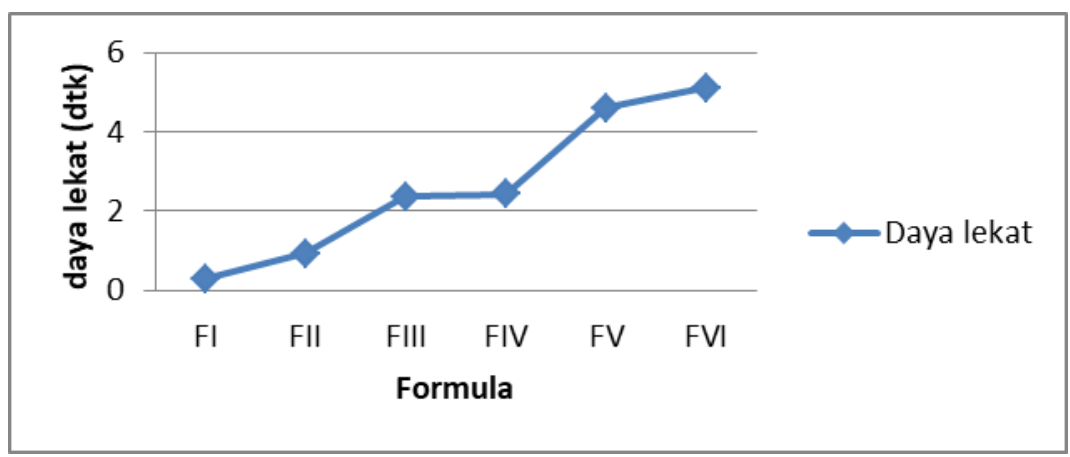

Gambar 3. Grafik hubungan uji daya lekat dengan formula gel minyak atsiri daun cengkeh.

Evaluasi Iritasi Gel Minyak Atsiri Daun Cengkeh

Evaluasi iritasi gel minyak atsiri daun cengkeh dilakukan dengan hewan uji marmot pada konsentrasi basis HPMC 3, 6, dan 10\% (FI, FIII, FV) serta konsentrasi basis yang sama dengan tambahan minyak atsiri $6 \%$ pada formula yang berbeda (FII, FIV, FVI). Pengamatan dilakukan dengan menggunakan metode Draize dan diamati terhadap eritema dan udema yang terjadi pada kulit marmut. Setelah dihitung skoring eritema dan udema yang terjadi, kemudian dihitung indeks iritasinya.

Indeks iritasi dari basis (FI, FIII, FV) dan sediaan gel daun cengkeh dengan variasi konsentrasi basis (FII, FIV, FVI) adalah tidak mengiritasi. Hasil pengamatan dapat dilihat pada Tabel 4 dan Tabel 5.

Tabel 4. Hasil iritasi formula gel minyak atsiri daun cengkeh

\begin{tabular}{cc}
\hline Kelompok Uji & Indeks Iritasi \\
\hline FI & 0 \\
FII & 0 \\
FIII & 0 \\
FIV & 0 \\
FV & 0 \\
FVI & 0 \\
\hline
\end{tabular}

Tabel 5. Hasil pengamatan uji iritasi

\begin{tabular}{ccccc}
\hline Kelompok & \multicolumn{4}{c}{ Waktu Pengamatan } \\
\cline { 2 - 5 } uji & \multicolumn{2}{c}{ Eritema } & \multicolumn{2}{c}{ Udema } \\
\cline { 2 - 5 } & 24 Jam & 72 Jam & 24 Jam & 72 Jam \\
\hline FI & 0 & 0 & 0 & 0 \\
FII & 0 & 0 & 0 & 0 \\
FIII & 0 & 0 & 0 & 0 \\
FIV & 0 & 0 & 0 & 0 \\
FV & 0 & 0 & 0 & 0 \\
FVI & 0 & 0 & 0 & 0 \\
\hline
\end{tabular}




\section{Simpulan}

Hasil penelitian menunjukkan bahwa minyak daun cengkeh sesuai dengan standar SNI. Hasil evaluasi sifat fisik gel, Formula $V$ dan FVI yang memenuhi persyaratan mutu fisik gel yang baik. Dari uji iritasi diketahui bahwa semua formula tidak menyebabkan iritasi pada kulit.

\section{Daftar Pustaka}

Agnihotri, S., Wakode, S. Agnihotri, A. 2016. Formulation and evaluation of herbal antiacne gel of Myrica Esculenta. Asian Journal of Pharmaceutical and Clinical Research, 9(4):109-113.

Daniel, A.N., Sartoretto, S.M., Schmidt, G., Caparroz-Assef, S.M., Bersani-Amado, C.A., Cuman, R.K.N. 2009. Anti-inflammatory and antinociceptive activities of eugenol essential oil in experimental animal models. Brazilian Journal of Pharmacognosy, 19(1B):212217.

Depkes RI. 1995. Farmakope Indonesia $4^{\text {th }}$ ed. Jakarta: Departemen Kesehatan Republik Indonesia.

Draelos, Z.D., Laurend, A.T. 2006. Cosmetic Formulation of Skin Care Products. New York: Taylor and Francis Group.

Draize, J.H. 1959. Dermal Toxicity. Austin: The Association of Food and Drug Officials of the United States, Bureau of Food and Drugs.
Gibson, M. 2001. Pharmaceutical Preformulation and Formulation. United States of America: CRC Press.

Irsan, Manggau, M.A., Pakki., E., Usmar. 2013. Uji iritasi krim antioksidan ekstrak biji lengkeng (Euphoria longana Stend) pada kulit kelinci (Oryctolagus cuniculus). Majalah Farmasi dan Farmakologi, 17(2):55-60.

Kibbe, A.H. 2004. Handbook of Pharmaceutical Exipients. Edisi ketiga. London: Pharceutical Press.

Ma, Q., Kineer, K. 2002. Chemoprotection by phenolic antioxidant, inhibition of tumor necrosis factor alpha induction in macrophages. The Journal of Biological Chemistry, 277:24772484.

Marwati, T., Rusli, S., Noor, E., Mulyono, E. 2005. Peningkatan mutu minyak daun cengkeh melalui proses pemurnian. Journal Penelitian Pascapanen Pertanian, 2(2):93-100.

Niazi, S.K. 2004. Handbook of Pharmaceutical Manufacturing Formulations: $\quad$ Semisolid Products. Florida: CRC Press LLC.

Nurdjannah, N. 2004. Diversifikasi tanaman cengkeh. Perspektif Review Penelitian Tanaman Industri, 3(2):61-70.

Nuryoto, Jayanudin, Hartoni, R. 2011. Karakterisasi minyak atsiri dari limbah daun cengkeh. Prosiding Seminar Nasional Teknik Kimia 
Kejuangan. 22 Februari 2011. Yogyakarta.

Pramod, K., Ansari, S.H., Ali, J. 2010. Eugenol: a natural compound with versatile pharmacological actions. Natural Product Communications, 5(12):19992006.

Prianto, H., Retnowati, R., Juswono, U.P. 2013. Isolasi dan karakterisasi dari bunga cengkeh kering hasil destilasi uap. Kimia Student Journal, 1(2):269-275.

Rowe, R.C., Sheskey, P.J., Quinn, M.E. 2009. Handbook of Pharmaceutical Excipient. Edisi keenam. London: Pharmaceutical Press Inc.

Sanjay, Jain B.D., Padsalg A., Patel, K., Mokale, V. 2007. Formulation development and evaluation of fluconazole gel in various polymer bases. Asian Journal of pharmaceutics, 1(1):63-68.

Voigt, R. 1994. Buku Pelajaran Teknologi Farmasi. $5^{\text {th }}$ ed. Yogyakarta: Gajah Mada University Press.

Wyatt, E.L., Sutter, S.H., Drake, L.A. 2008. Dermatology Pharmacology. In Gilman's the Parmacological Basis of Therapeutics. Hardaman, J.G., Limbird, L.E., Gilman, A.G. (eds). $10^{\text {th }}$ edition. New York: McGraw-Hill.

Zats, J.L., Gregory P.K. 1996. Gel. In Pharmaceutical Dosage Forms: Disperse Systems. Liebermen, H.A., Rieger, M.M., Banker, G.S. (Eds). New York: Marcel Dekker Inc. 